\title{
Using FDM and DEMATEL Approaches to Evaluate the Location Selection of Investment
}

\author{
Weng-Kun Liu
}

\begin{abstract}
The purpose of this study is to evaluate the important indicators of location selection for MNC overseas investment.The location selection is a vital issue when MNCs vigorously develop the global investment strategies to enhance their international competitive advantages. This research attempts to evaluate the factors of location selection as the following four steps: First, this research attempts to construct the initial indicators of location selection. Second, a focus group of MNCexperienced managers wasestablished to discover the factors of location selection relating to the evaluation of overseas investment. Third, Fuzzy Delphi method was applied to select the important evaluation criteria. Finally, the Decision Making Trial and Evaluation Laboratory (DEMATEL) approach is employed to explore the relevance among the factors of location selection.The research results indicate that Dimension one $D_{1}$ (Production Cost) has the highest degree of prominence $\left(d_{i}+r_{i}\right)$.Dimension five $D_{5}$ (Industry Characteristics) has the highest degree of effect $\left(d_{i}-r_{i}\right)$. The research results not only indicate the most important factors of dimension and criteria for location selection of investment, but also provide MNCs a valuable strategic guidance to select optimum location for carrying out overseas investment successfully.
\end{abstract}

Index Terms-Decision making trial and evaluation laboratory (DEMATEL), fuzzy delphi method (FDM), location selection.

\section{INTRODUCTION}

With the trend of rapid globalization, the overseas expansion has become increasingly important for Multinational Corporations (MNCs). The location selection therefore becomes a vital issue when MNCs vigorously invest across the borders and develop the global strategies to enhance their international competitive advantages in the competitive world market.Decisions on location selection can widely influence business strategic planning and operational profit. Corporations use various tools in selecting locations for capital investment and consider numerous factors in determining the optimal sites for the investment.These factors will vary from industry to industry, but several important factors have to be considered, including production cost, investment environment, public infrastructure, government policy, and industry characteristics. The decision of choosing the investment locationis important for MNCs.Thus, careful assessing for the investment environment and selecting a suitable site are the important factors for the overseas investment.Thedecision criteria of location selections will be investigatedwhen MNCs consider overseas investment.This

Manuscript received May 6, 2014; revised July 23, 2014.

Weng-Kun Liu is with Feng Chia University, Taiwan (e-mail: wengkun2004@yahoo.com). research intends to evaluate the location selection of investment in Vietnam as the following steps. First, this research attempts to construct the initial indicators of location selections. Second, a focus group of MNC managers with abundant experiences was established to evaluate theprimary factors oflocation selections relating to the investment in Vietnam. Third, the important factors related to the evaluation criteria of location selections are selected by using Fuzzy Delphi method.Fourth, the important indicators of location selection are determined by applyingthe Decision Making Trial and Evaluation Laboratory(DEMATEL) approach, which is an analytical method of structural model used to clarify the essential of the problem. The research results not only provide MNCs a valuable reference to improve the model of location selection, but also provide appropriate strategicguidanceto carry out overseas investment successfully.

\section{The CONCEPTUAL FRAMEWORK OF THE RESEARCH}

To assure the accuracy of selection process, this study combined with several research methods, including both qualitative and quantitative research methods to evaluate the location selection of overseas investment. This research intends to evaluate the factors of location selectionas the following four steps: First, this research attempts to construct the initial indicators of location selection. Second, a focus group of MNCexperienced managers wasestablished to discover the factors of location selection relating to the evaluation of overseas investment.Third, Fuzzy Delphi method was applied to select the important evaluation criteria. Forth, the Decision Making Trial and Evaluation Laboratory(DEMATEL) approach is employed to explore the relevance among the factors of location selection. The whole research processes of this study were divided into the following four steps:

\section{A. Step One: Establishing the Initial Indicators of Location Selection}

The first step was to construct the structure of initial indicators of location selection.

\section{B. Step Two: Focus Group Method}

A focus group composed by MNC experienced managers was established to define the indicators of location selection. A focus group method was employed to develop and construct the essential indicators of location selection related to the overseas investment [1].

\section{Step Three: Fuzzy Delphi Method(FDM)}

The FDM was developed to 1) build the structure of location selection; 2) set up the evaluations of weights; and 3) 
select the important criteria of location selection for MNC overseas investment [2].

\section{Step Four: Decision Making Trialand Evaluation Laboratory (DEMATEL) Method}

DecisionMaking Trial and Evaluation Laboratory (DEMATEL) method was used tobuild an influential relationship among dimensions and criteria. It uses matrix and related math theories to calculate the cause and effect on each element in the degree. This method is widely used to solve various types of complex studies that can effectively understand the complex structure and provide viable options of problem-solving [3].

\section{LITERATURE REVIEW}

Location selection plays a vital aspect of cross-border investment nowadays [4]. Brimberg and Love [5] indicated the problem of location decision process, including the identification, analysis, evaluation and final decision of selection among location alternatives. The location decision is among the most critical decision of distribution network and a multi-criteria decision making problem [6]. Such a poor location decision might result in detrimental operations, labor shortage, and loss of competitive advantage because MNCs have to undertake any reverse costly and entail a long-term commitment [7].

Location theory is the theory about the spatial distribution of human activitiesand relations. Specifically, the theory involves the theoretical study of human economic behavior of spaceand spatial locationof economic activityin the region, entailing the optimal portfolio choice withina certain geographical space [8]. The decision making of location selection contains the following factors, such as the impact of resources, population, transportation, education, the level of development of industry, consumption levels, government policiesand other factors affected the region, the impact of the economic activity and production processes [9].

Two key theories of location selection are indicated as follows

\section{A. The Eclectic Paradigm of International Production}

Ohlin, Hesselborn, and Wijkman [10] proposed the primary concept of the eclectic paradigm of international production, which indicated three key factors that determine the international activities of MNCs, including ownership (O) advantages, location (L) advantages, and internalization (I) advantages. Therefore, the eclectic paradigm is known as the OLI paradigm, which explains outward foreign direct investment (FDI).

\section{B. Ownership Advantages}

Ownership advantages could be explained as competitive advantages that derive from a corporate special technological or managerial knack [11]. Usually, foreign companies are more difficult to enter a market than domestic companies due to the spatial, cultural and linguistic distances between the host country and home country.

\section{Locational Advantages}

Based on economic differences between countries, the locational advantages could be developed by the production in the local area. Dunning [12]sorted out the key factors of distinct endowments from different countries. Contrary to neoclassical approaches, he removed the limited factors and transferredintermediate products and know-how across the country borders.

\section{Internalization Advantages}

As the effect of market competition, different MNCs involve different business costs by coordinating cross-border transactions [13]. MNCs could exploit a competitive advantageby setting up an overseas subsidiary rather than selling products across the borders. Internalization advantages could be developed by making use of the competitive advantage from different countries.

The relationship between market entry and strategic advantage is listed as shown in Table I.

TABLE I: RELATIONSHIP BETWEEN MARKET ENTRY AND STRATEGIC

\begin{tabular}{lccc} 
& \multicolumn{3}{c}{ ADVANTAGES } \\
& $\begin{array}{l}\text { Ownership } \\
\text { advantages }\end{array}$ & $\begin{array}{l}\text { Locational } \\
\text { advantages }\end{array}$ & $\begin{array}{l}\text { Internalization } \\
\text { advantages }\end{array}$ \\
\hline $\begin{array}{l}\text { Direct } \\
\text { Investment }\end{array}$ & Yes & Yes & Yes \\
\hline Export & Yes & No & Yes \\
\hline Licensing & Yes & No & No \\
\hline
\end{tabular}

Source: Stüting, Dorow, Blazejewski, and Claassen (2003) [14].

\section{E. Alfred Weber's Theory of Industrial Location}

The theory of industrial location was established by Alfred Weber [15], who indicated that the optimal selection of location is based on the minimum transportation costs of raw materials and products. The assumptions of theory are that transportation costs are proportional to the product weight and distance costs of raw material and finished products.A corporate could select the optimal manufacturing location by considering the following three variables of production: the material index, the input of labor, and agglomeration economics.

The material index, the first variable of location selection, is used to evaluate the input costs of production. The radio of the weight of raw material to that of the finished product is composed to be the material index, which is applied to evaluate whether corporates locates their factories near the raw material or the market. The optimal selection of geographic location is based on the level of material index, which indicates the level of input costs of manufacturing products. That is, a firm with high material index would select the location near the raw material. On the contrary, a firm with low material index would select the location near the market.

The second variable of location selection, the labor cost, which is applied to evaluate the input costs of production. The lower labor costs could justify the transportation costs to and from these areas. However, the cheaper labor may be far away from the places of markets and raw materials. If the opportunity cost of the added transportation is less than that of the lower labor costs, corporates could make use of this advantage to select the location near the area with cheaper labor.

The third variable of location selection is agglomeration economics, which is used to evaluate the input costs of production. Agglomeration economics exist when a large number of firms with a particular industry gather in one small 
geographic area. The advantagesof agglomeration economics allow these firms to select the location in a cluster area byintegratingtheir productions with other firms.

\section{INVESTMENT ENVIRONMENT IN VIETNAM}

Since 1986, Vietnam has been transited from a central planned economy to dense populated developing society. Vietnam authorities had confirmed their commitments to strengthen modernized economy in recent years. In 2007, Vietnam became an official member of the World Trade Organization (WTO), which has created more competitive industrial industries in domestic markets.In 2010,Vietnam joined the Trans-Pacific Partnership Trade Agreement, which had caused agriculture share of economic output to shrink from $25 \%$ in 2000 to $22 \%$ in 2012 [16]. Meanwhile, industry share of economic output increased from $36 \%$ to $41 \%$. Vietnam is trying to enhance employment rate and increase industrial development in recent years.

Although global recession hurt export-oriented economy since 1999, Vietnam's exports increased by more than $18 \%$ in 2012. Vietnam administrative actions had brought the trade deficit into balance and create more jobs to meet the challenge of industrial development. Vietnam made effort to carry out currency reform, which caused the currency devaluation over 20\% between 2008 and 2011 [17]. However, the Vietnam Dong (VND), the currency of Vietnam, remained stable in 2012.

Vietnam has devoted to promoting economic development and emphasized macroeconomic stability through tighter monetary policy and fiscal adjustment in recent years. As shown in Table II, the real growth rate of Gross Domestic Product (GDP) is recorded as 5.03 percent in 2012 [18]. According to the General Statistics Office of Vietnam, the export revenue of 2012 totaled 114.631 billion USD while import turnover of 2012 reached 114.347 billion USD, representing a trade surplus of 284 million USD [19].

\begin{tabular}{ll}
\multicolumn{2}{c}{ TABLE II: VIETNAM ECONOMY PROFILE OF 2012} \\
\hline Item & Data \\
\hline GDP/Purchasing Power Parity & $\$ 325.9$ Billion \\
\hline GDP/Real Growth Rate & $5.03 \%$ \\
\hline GDP/Per Capita & $\$ 3,600$ \\
\hline Gross National Saving & $37.4 \%$ of GDP \\
\hline Labor force & 49.18 Million \\
\hline Unemployment Rate & $4.3 \%$ \\
\hline Investment & $28.2 \%$ of GDP \\
\hline Public Debt & $48.2 \%$ of GDP \\
\hline Inflation Rate & $9.1 \%$ \\
\hline Exports & $\$ 114.529$ Billion \\
\hline Imports & $\$ 113.781$ Billion \\
\hline Trade Surplus & $\$ 748$ Million \\
\hline Source: Indexmundi (2013) [20]
\end{tabular}

\section{FUZZY DELPHI METHOD}

The Delphi method aims to improve group decision making by seeking opinions without face-to-face interaction and is commonly described as "a method of systematicsolicitation and collection of judgments on a particular topicthrough a set of carefully designed sequential questionnaires, interspersed with summarized information and feedback of opinions derived from earlier responses" [21], [22].
Among thegroup-decision methods, Delphi Method is one of the most used methods that have usually been applied. The group-decision method is frequently used approach to survey the opinions of experts in the specific fields with questionnaires [23]. If there is noconsensus or exchange of ideas among experts, the negotiator will integrate the opinions fromthe experts and select the average or $50 \%$ of the result as the collective opinion. If the resultdoes not satisfy the standard of convergence, the surveymust be repeated until the standard issatisfied. Therefore, the problems of the traditional Delphi Method are that opinions fromthe experts might not easily satisfy the standard of convergence [24]; the survey would often needto be repeated several times until the acceptable standard is reached, which might result inhigh expenses of the capital and time; and with the decrease of response rate, the negotiator'ssubjective opinions might affect the result.

Therefore, if the Fuzzy theory could be applied to theDelphi Method, not only the merit that the result obtained could be similar to that obtainedby the traditional Delphi Method, but also the repeating time for survey could be reduced and the cost could be decreased. In particular, the individual features of each expertcould be reflected and the professional knowledge of each expert would be applied more reasonablyand suitably [25].

Therefore, this study adopts the reformed Fuzzy Delphi Method (FDM) which is based on triangularfuzzy numbers. The FDM method was applied to select the location selection of overseas investment, because it not only solved the disadvantages resulting fromthe conventional Delphi Method, but also because its results would not easily be affectedby extreme opinions. Finally, the procedureof adopting the Fuzzy Delphi Method to the structure of location selection for MNC overseas investment is described as follows:

\section{A. Step One: Building the Structure of Managerial Competences for MNC Executives.}

The initial setting of location selection for MNC overseas investmentcould be discussed from 5dimensions, including1) production cost, 2) infrastructure, 3) investment environment, 4) government policy, and 5) industry characteristics.

\section{B. Step Two: Setting up the Evaluations of Weights}

By using the triangular fuzzy numbers to integrate the opinions from experts, the problemsof fuzzy human thoughts and inaccuracy were reduced. Additionally, the decision maker'sreal attempt could be more clarified. The approaches to integrating the group opinions wereaverage numbers, total numbers, the maximum, the minimum, and the hybrid method ofaveraging the maximum and the minimum. As pointed by Saaty[26], the expert opinionswould be better presented using the geometric average method, which has been applied frequentlyin practical studies.Moreover, because the result from the geometric average methodwould be suitable for defining the fuzzy judgment matrix, this study used geometric averagesto obtain the collective opinions from experts. Hence, the triangular fuzzy numbers, which are the fuzzy numbers most often used, were adopted, to set up the fuzzy membershipfunction of the experts' opinions, which is shown in Fig. 1. This chartpresents the minimum of the experts' common consensuses as point 1 , and the maximum aspoint $\mathrm{u}$.Accordingly, the satisfaction degree to 
these two extremes would be presented as 0,while the segments between 1 and $\mathrm{u}$ would be given the satisfaction degree between 0 and1. Hence, this study includes the fuzzy number of all expert opinions, which is representedas $\widetilde{\boldsymbol{W}}_{i j}=(l$, $m, u) \mathrm{L}-\mathrm{R}$, whereas the fuzzy weight number of the indicator for the managerialcompetence indicator $\mathrm{j}$ by an individual expert i would be $\widetilde{\boldsymbol{W}}_{i j}=(l i j, m i j, u i j) \mathrm{L}-\mathrm{R}$. Consequently, the approach described above could prevent information being deleted, as happenedin the traditional Delphi Method, and the common consensuses included as many expertsas possible.

As listed below, Fig. 1 and Fig. 2 show the comparison of the traditional Delphi method and the Fuzzy Delphi method.

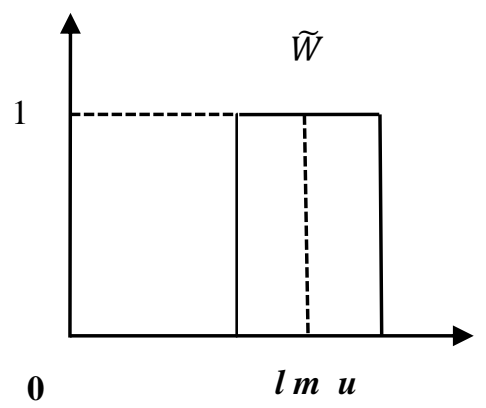

Fig. 1. The traditional Delphi method.

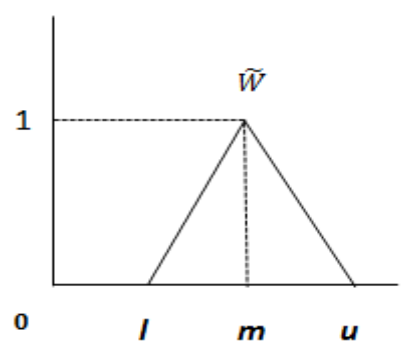

Fig. 2. The fuzzy Delphi method.

The evaluations of fuzzy weights from the experts were therefore obtained from the surveyof Fuzzy Delphi Method. Hence, the fuzzy weight number of expert $i$ on location selection indicator $\mathrm{j}$ could be presented as follows:

$$
\begin{gathered}
\widetilde{\mathrm{W}}_{i j}=\left(l_{i j}, m_{i j}, u_{i j}\right)_{L-R} \\
l_{j}=\operatorname{Min}\left(l_{i j}\right), i=1,2,{ }^{\mathrm{mx}}, n ; j=1,2,{ }^{\mathrm{mx}}, m \\
m_{j}=\left(\prod_{i=1, j=1}^{n, m} m_{i j}\right)^{\frac{1}{n}}, i=1,2,{ }^{m \times x}, n ; j=1,2,{ }^{m \times}, m \\
u_{j}=\operatorname{Max}\left(u_{i j}\right), i=1,2, \ldots, n ; j=1,2, \ldots, m
\end{gathered}
$$

where $n$ stands for the numbers of experts, and $m$ represents the numbers of indicators for location selection.

\section{Step Three: Selecting the Criteria of Location Selection}

The fuzzy weight number $\widetilde{\boldsymbol{W}}_{i j}$ generated from Step Two could not be used for directcomparison. Therefore, this study employed the fuzzy mean and spread method [27], [28], transforming the result into a crisp number of $A_{j}$.

$$
A_{j}=\frac{u_{j}+m_{j}+l_{j}}{3}, j=1,2, \cdots, m
$$

Then experts provided a threshold. Referring to previous studies on location selection, the threshold was set as b, which was used to select importantcriteria of location selection.

If $A_{j} \geq b$, then the criteriaof location selection should be selected;

If $A_{j}<\mathrm{b}$, then the criteriaof location selection should be deleted.

\section{DEMATEL METHOD}

DEMATEL is an analytical method of structural model. It is mainly used to solve all kinds of complex problems to clarify the essential of the problem. It uses matrix and related math theories to calculate the cause and effect on each element in the degree [29]. DEMATEL method is widely used to solve various types of complex studies that can effectively understand the complex structure and provide viable options of problem-solving.

DEMATEL is divided into the following five steps:

The first step is to confirm the system has n elements and develop the evaluating scale, using pair of dimensions to compare and also using evaluating scale $0,1,2,3,4$, which in turn represents no effect (0), low effect 1 ), medium effect 2 ), high effect 3 ), and extremely high effect 4) as measuring standard.

The second step is to calculate initial matrix, using pair of degree of interaction to obtain directly effecting matrix $=$ $\left[Z_{i j}\right]_{n \times n}$, where $\mathbf{Z}_{\mathbf{i j}}$ represents the degree of effect on $\mathbf{i}$ factor effects $\mathrm{j}$ factor as shown in Equation (6) [30], [31]. When the elements of $i$ have a direct effect on the elements of $j$, then $z_{i j} \neq 0$, opposite $z_{i j}=0$

$$
Z_{i j}=\left[\begin{array}{ccccc}
Z_{11} & \cdots & Z_{1 j} & \cdots & Z_{1 n} \\
\vdots & & \vdots & & \vdots \\
Z_{i 1} & \cdots & Z_{i j} & \cdots & Z_{i n} \\
\vdots & & \vdots & & \vdots \\
Z_{n 1} & \cdots & Z_{n j} & \cdots & Z_{n n}
\end{array}\right]
$$

The third step is to normalize the matrix. It can be obtained from Equation (7) and (8). Its diagonal is 0 , and maximum sum of row or column is 1 .

$$
\begin{gathered}
X=s Z \\
\mathrm{~s}=\min \left[\frac{1}{\max _{j} \sum_{j=1}^{n}\left|Z_{i j}\right|}, \frac{1}{\max _{j} \sum_{j=1}^{n}\left|Z_{i j}\right|}\right], i, j=1,2, \ldots, n
\end{gathered}
$$

The forth step is to obtain the total effect matrix $\mathbf{T}$. It can be obtained from Eq. (9), where I is the identity matrix.

$$
T=X+X^{2}+\cdots+X^{\ell}=X(I-X)^{-1},
$$

when

$$
\lim _{\ell \rightarrow \infty} X^{\ell}=[0]_{n \times n}
$$

The fifth step is to obtain the prominence and relation. To sum of each row and column of the total effect matrix $\mathrm{T}$.

$$
T=\left[t_{i j}\right], i, j=1,2, \ldots, n
$$

It will obtain the sum of all rows (vectord = $\left(\mathbf{d}_{\mathbf{1}}, \cdots \mathbf{d}_{\mathbf{i}}, \cdots \mathbf{d}_{\mathbf{n}}\right)$ ) and the sum of all columns (vectorr $=$ 
$\left.\left(\mathbf{r}_{1}, \cdots \mathbf{r}_{\mathbf{i}}, \cdots \mathbf{r}_{\mathbf{n}}\right)\right)$. If $\mathbf{d}_{\mathbf{i}}$ represents the sum of all rows of the total effect matrix $\mathbf{T}$, meaning directly or indirectly affects degree; $\mathbf{r}_{\mathbf{i}}$ represents the sum of all columns of the total effect matrix $\mathbf{T}$, meaning affected by other criteria.

$$
\begin{aligned}
& d=\left[\mathrm{d}_{i}\right]_{n \times 1}=\left[\sum_{j=1}^{n} t_{i j}\right]_{n \times 1} \\
& r=\left[r_{i}\right]_{n \times 1}=\left[\sum_{i=1}^{n} t_{i j}\right]_{1 \times n}^{\prime}
\end{aligned}
$$

where

$d_{i}$ represents the factor which will affect other factors, $r_{i}$ represents the factor that is affected by other factors.

According to the definition, $\left(\mathbf{d}_{\mathbf{i}}+\mathbf{r}_{\mathbf{i}}\right)$ presents the degree of relationship between the factors, meaning "prominence"; comparatively, $\left(\mathbf{d}_{\mathbf{i}}-\mathbf{r}_{\mathbf{i}}\right)$ presents the degree of effect and effected for the factors, meaning "relation"[32]. If $\left(\mathbf{d}_{\mathbf{i}}-\mathbf{r}_{\mathbf{i}}\right)$ is positive, then factor $i$ is affecting other factors; if $\left(\mathbf{d}_{\mathbf{i}}-\mathbf{r}\right)$ is negative, then factor iis being affected by other factors.

\section{EMPIRICAL RESEARCH ANALYSIS}

\section{A. Applications of the Fuzzy Delphi Method}

A focus group method is employed to developand construct the essential dimensions and criteria oflocation selection forMNCinvestment. A focus group of 20 experts wasestablished to participate in the survey and construct the structure of the location selection.After establishing the initial structure of criteria, the Fuzzy Delphi Method is developed to identify the important criteria of location selection.

The fuzzy weight number $\widetilde{\boldsymbol{W}}_{i j}$ could not be used for directcomparison. This study therefore employed the fuzzy mean and spread method, transforming the result into a crisp number of $A_{j}$.

The thresholdof location selection criteria is set as $b$ $=0.811$;

If $A_{j} \geq 0.811$, then the indicator of location selection should be selected;

If $A_{j}<0.811$, then the indicator of location selection should be deleted

As shown in Table III, the calculated result of the Fuzzy Delphi Method is obtained. Most of the indicators in these five dimensions are retained. However, two criteria are deleted in the dimension of production cost (D1), including construction costs (C15) and raw material costs (C16). Only one criterionis deleted from the dimension of investment environment (D3), including Protection of lifeand property (C38). After deleting the above3 less important criteria, total 28 initial criteria of location selectionare reduced to 25 criteria.

\section{B. Measurement of DEMATEL Method}

According to Eq. (11), the total influence given and received on dimensions was constructed by the $\mathbf{d}_{\mathbf{i}}$ and $\mathbf{r}_{\mathbf{i}}$ in the total direct-influence matrix $\mathbf{T}$ in Table IV.

\begin{tabular}{|c|c|c|c|c|}
\hline Dimensions & & Criteria & Crisp Number & Threshold $b=0.811$ \\
\hline \multirow{6}{*}{$\begin{array}{c}\mathrm{D}_{1} \\
\text { Production Cost }\end{array}$} & $\mathrm{C}_{11}$ & Transportation costs & 0.889 & \\
\hline & $\mathrm{C}_{12}$ & Energy supply costs & 0.842 & \\
\hline & $\mathrm{C}_{13}$ & Labor wage levels & 0.836 & \\
\hline & $\mathrm{C}_{14}$ & Land costs & 0.879 & \\
\hline & $\mathrm{C}_{15}$ & Construction costs & 0.781 & Delete \\
\hline & $\mathrm{C}_{16}$ & Raw material costs & 0.770 & Delete \\
\hline \multirow{5}{*}{$\mathrm{D}_{2}$ Infrastructure } & $\mathrm{C}_{21}$ & Rail and road facilities & 0.882 & \\
\hline & $\mathrm{C}_{22}$ & Seaport facilities & 0.834 & \\
\hline & $\mathrm{C}_{23}$ & Airport facilities & 0.841 & \\
\hline & $\mathrm{C}_{24}$ & Medical environment & 0.858 & \\
\hline & $\mathrm{C}_{25}$ & Infrastructure & 0.848 & \\
\hline \multirow{8}{*}{$\begin{array}{c}\mathrm{D}_{3} \\
\text { Investment Environment }\end{array}$} & $\mathrm{C}_{31}$ & Social systems & 0.832 & \\
\hline & $\mathrm{C}_{32}$ & Natural environment & 0.828 & \\
\hline & $\mathrm{C}_{33}$ & Economic conditions & 0.852 & \\
\hline & $\mathrm{C}_{34}$ & Communication quality & 0.845 & \\
\hline & $\mathrm{C}_{35}$ & Environmental regulations & 0.811 & \\
\hline & $\mathrm{C}_{36}$ & Labor supply & 0.841 & \\
\hline & $\mathrm{C}_{37}$ & Labor force quality & 0.882 & \\
\hline & $\mathrm{C}_{38}$ & Protection of lifeand property & 0.761 & Delete \\
\hline \multirow{5}{*}{$\begin{array}{c}\mathrm{D}_{4} \\
\text { Government Policy }\end{array}$} & $\mathrm{C}_{41}$ & Government Service & 0.862 & \\
\hline & $\mathrm{C}_{42}$ & Administrative efficiency & 0.885 & \\
\hline & $\mathrm{C}_{43}$ & Incentives and tax & 0.845 & \\
\hline & $\mathrm{C}_{44}$ & Financial Institutions & 0.848 & \\
\hline & $\mathrm{C}_{45}$ & Corporate preferential treatment & 0.845 & \\
\hline \multirow{4}{*}{$\begin{array}{c}\mathrm{D}_{5} \\
\text { Industry Characteristics }\end{array}$} & $\mathrm{C}_{51}$ & Industry cluster & 0.835 & \\
\hline & $\mathrm{C}_{52}$ & Agglomeration economy & 0.841 & \\
\hline & $\mathrm{C}_{53}$ & Economies of scale & 0.896 & \\
\hline & $\mathrm{C}_{54}$ & IndustrialCompetitiveness & 0.868 & \\
\hline
\end{tabular}

TABLE III: THE CRITERIA OF LOCATION SELECTION BY USING FUZZY DELPHI METHOD 
Tzeng, Chiang, and Li [33] demonstrated that $\left(\mathbf{d}_{\mathbf{i}}+\mathbf{r}_{\mathbf{i}}\right)$ represents the degree of relationship between the factors, meaning "prominence".As shown in Table IV, D1 (Production Cost) has the highest degree of prominence $\left(\mathbf{d}_{\mathbf{i}}+\mathbf{r}_{\mathbf{i}}\right)$. The ranking of prominence is listed from the highest to the least value as follows: D1 (Production Cost), D3 (Investment Environment), D4 (Government Policy), D2 (Infrastructure), and D5 (Industry Characteristics).

Comparatively, $\left(\mathbf{d}_{\mathbf{i}}-\mathbf{r}_{\mathbf{i}}\right)$ presents the degree of effect and effected for the factors, meaning "relation". As shown in Table IV, D5 (Industry Characteristics) has the highest degree of effect $\left(\mathbf{d}_{\mathbf{i}}-\mathbf{r}_{\mathbf{i}}\right)$. The ranking of relationis listed from the highest to the least value as follows: D5 (Industry Characteristics), D4 (Government Policy), D2 (Infrastructure), D1 (Production Cost), and D3 (Investment Environment).

TABLE IV: THE TOTAL INFLUENCE GIVEN / RECEIVED FOR DIMENSIONS

\begin{tabular}{ccccccc}
\hline Dimensions & $\mathbf{d}$ & $\mathbf{r}$ & $\mathbf{d}+\mathbf{r}$ & Rank & d-r & Rank \\
\hline $\mathbf{D}_{\mathbf{1}}$ & 2.14 & 2.25 & 4.39 & $\mathbf{1}$ & -0.11 & $\mathbf{4}$ \\
\hline $\mathbf{D}_{\mathbf{2}}$ & 2.20 & 2.05 & 4.25 & $\mathbf{4}$ & 0.15 & $\mathbf{3}$ \\
\hline $\mathbf{D}_{\mathbf{3}}$ & 2.07 & 2.27 & 4.34 & $\mathbf{2}$ & -0.20 & $\mathbf{5}$ \\
\hline $\mathbf{D}_{\mathbf{4}}$ & 2.26 & 2.04 & 4.30 & $\mathbf{3}$ & 0.22 & $\mathbf{2}$ \\
\hline $\mathbf{D}_{\mathbf{5}}$ & 2.21 & 1.97 & 4.18 & $\mathbf{5}$ & 0.24 & $\mathbf{1}$ \\
\hline
\end{tabular}

As shown in Fig. 3, dimension D5 affects the other four dimensions: D4, D1, D3, and D2 (D5 $\left.\rightarrow\left\{\mathbf{D}_{\mathbf{4}}, \mathbf{D}_{\mathbf{1}}, \mathbf{D}_{3}, \mathbf{D}_{\mathbf{2}}\right\}\right)$. From these influential relationships, MNC should first improve D5 (Industry Characteristics), then the other four dimensions D4 (Government Policy), D1 (Production Cost), D3 (Investment Environment), and D2 (Infrastructure) will be improved.

Dimension D4 affects dimension D1 and D3 (D4 $\rightarrow$ $\left\{\mathbf{D}_{1}, \mathbf{D}_{\mathbf{3}}\right\}$ ). MNC should improve D4 (Government Policy), then the other two dimensions: D1 (Production Cost) and D3(Investment Environment) will be improved.

Dimension D2 affects dimension D1 and D3 (D4 $\rightarrow$ $\left\{\mathbf{D}_{1}, \mathbf{D}_{3}\right\}$ ). MNC should improve D2 (Infrastructure), then the other two dimensions: D1 (Production Cost) and D3(Investment Environment) will be improved.

Dimension D1 affects dimension D3 (D1 $\left.\rightarrow\left\{\mathbf{D}_{3}\right\}\right)$. MNC should improve D1 (Production Cost), then the other dimension: D3 (Investment Environment) will be improved.

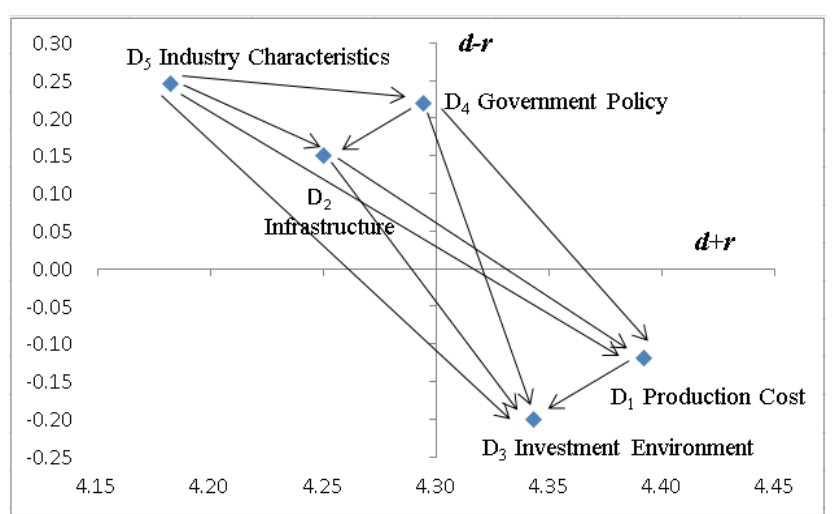

Fig. 3. The impact-relations-map of relations within dimensions ofthelocation selection.

As shown in Table V, C32 (Natural Environment) has the highest degree of prominence $\left(\mathbf{d}_{\mathbf{i}}+\mathbf{r}_{\mathbf{i}}\right)=6.28$, which represents the degree of relationship among the criteria of location selection. The top five criteria for the degree of prominence are ranked in order as follows: C32 (Natural Environment), C37 (Labor Force quality), C33 (Economic Conditions), C35 (Environmental Regulations), and C34 (Communication Quality).

Comparatively, C31 (Social Systems) has the highest degree of relation $\left(\mathbf{d}_{\mathbf{i}}-\mathbf{r}_{\mathbf{i}}\right)$, which represents the degree of effect among the criteria of location selection. The top five criteria for the degree of relation are ranked in order as follows: C31 (Social Systems), C36 (Labor Supply), C42 (Administrative Efficiency), C41 (Government Service), and C14 (Land Costs).

\begin{tabular}{|c|c|c|c|c|c|c|c|}
\hline Dimension & Criteria & $\mathrm{d}$ & $\mathrm{r}$ & $\mathrm{d}+\mathrm{r}$ & $\mathrm{R}$ & d-r & $\mathrm{R}$ \\
\hline \multirow[t]{4}{*}{$D_{1}$} & $\mathrm{C}_{11}$ & 1.67 & 1.7 & 3.37 & 3 & -0.03 & 4 \\
\hline & $\mathrm{C}_{12}$ & 1.73 & 1.75 & 3.47 & 2 & -0.02 & 3 \\
\hline & $\mathrm{C}_{13}$ & 1.75 & 1.74 & 3.49 & 1 & 0.02 & 2 \\
\hline & $\mathrm{C}_{14}$ & 1.68 & 1.65 & 3.35 & 4 & 0.05 & 1 \\
\hline \multirow[t]{5}{*}{$\mathbf{D}_{2}$} & $\mathrm{C}_{21}$ & 2.31 & 2.28 & 4.59 & 2 & 0.03 & 2 \\
\hline & $\mathrm{C}_{22}$ & 2.34 & 2.30 & 4.64 & 1 & 0.03 & 3 \\
\hline & $\mathrm{C}_{23}$ & 2.27 & 2.22 & 4.48 & 5 & 0.05 & 5 \\
\hline & $\mathrm{C}_{24}$ & 2.27 & 2.26 & 4.54 & 3 & 0.01 & 4 \\
\hline & $\mathrm{C}_{25}$ & 2.19 & 2.31 & 4.50 & 4 & -0.12 & 5 \\
\hline \multirow[t]{7}{*}{$\mathbf{D}_{3}$} & $\mathrm{C}_{31}$ & 3.20 & 2.86 & 6.06 & 7 & 0.33 & 1 \\
\hline & $\mathrm{C}_{32}$ & 3.01 & 3.27 & 6.28 & 1 & -0.26 & 7 \\
\hline & $\mathrm{C}_{33}$ & 3.08 & 3.13 & 6.21 & 3 & -0.06 & 4 \\
\hline & $\mathrm{C}_{34}$ & 3.07 & 3.05 & 6.13 & 5 & 0.02 & 3 \\
\hline & $\mathrm{C}_{35}$ & 3.03 & 3.12 & 6.15 & 4 & -0.09 & 6 \\
\hline & $\mathrm{C}_{36}$ & 3.10 & 2.98 & 6.09 & 6 & 0.12 & 2 \\
\hline & $\mathrm{C}_{37}$ & 3.08 & 3.15 & 6.23 & 2 & -0.06 & 5 \\
\hline \multirow[t]{5}{*}{$\mathbf{D}_{4}$} & $\mathrm{C}_{41}$ & 2.12 & 2.06 & 4.18 & 5 & 0.06 & 2 \\
\hline & $\mathrm{C}_{42}$ & 2.15 & 2.06 & 4.21 & 4 & 0.09 & 1 \\
\hline & $\mathrm{C}_{43}$ & 2.12 & 2.20 & 4.32 & 2 & -0.08 & 5 \\
\hline & $\mathrm{C}_{44}$ & 2.14 & 2.18 & 4.33 & 1 & -0.04 & 4 \\
\hline & $\mathrm{C}_{45}$ & 2.10 & 2.12 & 4.22 & 3 & -0.02 & 3 \\
\hline \multirow[t]{4}{*}{$D_{5}$} & $\mathrm{C}_{51}$ & 1.67 & 1.64 & 3.30 & 1 & 0.03 & 2 \\
\hline & $\mathrm{C}_{52}$ & 1.64 & 1.63 & 3.25 & 2 & 0.01 & 3 \\
\hline & $\mathrm{C}_{53}$ & 1.48 & 1.44 & 2.91 & 4 & 0.04 & 1 \\
\hline & $\mathrm{C}_{54}$ & 1.59 & 1.66 & 3.25 & 3 & -0.07 & 4 \\
\hline
\end{tabular}

Within dimension of Production Cost (D1), C13 (Labor wage levels) has the highest degree of prominence $\left(\mathbf{d}_{\mathbf{i}}+\mathbf{r}_{\mathbf{i}}\right)=$ 3.49, and C14 (Land costs) has the highest value of effect $\left(\mathbf{d}_{\mathbf{i}}-\mathbf{r}_{\mathbf{i}}\right)=0.05$, which demonstrates that C14affects the other three criteria $\mathrm{C} 13, \mathrm{C} 12$ and $\mathrm{C} 11$. That is, MNC should first improve $\mathrm{C} 14$ (Land costs), then the other three criteria: C13 (Labor wage levels), C12 (Energy supply costs) and C11(Transportation costs) will be improved.

Within dimension of Infrastructure (D2), C22 (Seaport facilities) has the highest degree of prominence $\left(\mathbf{d}_{\mathbf{i}}+\mathbf{r}_{\mathbf{i}}\right)=$ 4.64, and C23 (Political and Economic conditions) has the highest value of effect $\left(\mathbf{d}_{\mathbf{i}}-\mathbf{r}_{\mathbf{i}}\right)=0.05$, which demonstrates that $\mathrm{C} 23$ affects the other four criteria C21, C22, C24, and $\mathrm{C} 25$. That is, MNC should first improve C23 (Airport facilities), then the other four criteria: C21 (Rail and road facilities), C22 (Seaport facilities), C24 (Medical environment), and C25 (Infrastructure) will be improved.

Within dimension of Investment Environment (D3), C32 (Natural environment) has the highest degree of prominence 
$\left(\mathbf{d}_{\mathbf{i}}+\mathbf{r}_{\mathbf{i}}\right)=6.28$, and C31 (Social systems) has the highest value of effect $\left(\mathbf{d}_{\mathbf{i}}-\mathbf{r}_{\mathbf{i}}\right)=0.33$, which demonstrates that C31 affects the other seven criteria C32, C33, C34, C35, C36, C37, and C38. That is, MNC should first improve C31 (Social systems), then the other three criteria: C32 (Natural environment), C33 (Economic conditions), C34 (Communication quality), C35 (Environmental regulations), C36 (Labor supply), C37 (Labor force quality), and C38 (Protection of life and property) will be improved.

Within dimension of Government Policy (D4), C44 (Financial Institutions) has the highest degree of prominence $\left(\mathbf{d}_{\mathbf{i}}+\mathbf{r}_{\mathbf{i}}\right)=4.33$, andC42 (Administrative efficiency) has the highest value of effect $\left(\mathbf{d}_{\mathbf{i}}-\mathbf{r}_{\mathbf{i}}\right)=0.09$, which demonstrates that $\mathrm{C} 42$ affects the other four criteria C41, C43, C44, and C45. That is, MNC should first improve C42 (Administrative efficiency), then the other three criteria: C41 (Government Service), C43 (Incentives and tax), C44 (Financial Institutions), and C45 (Corporate preferential treatment) will be improved.

Within dimension of Industry Characteristics (D5), C51 (Industry cluster) has the highest degree of prominence $\left(\mathbf{d}_{\mathbf{i}}+\mathbf{r}_{\mathbf{i}}\right)=3.30$, andC53 (Economies of scale) has the highest value of effect $\left(\mathbf{d}_{\mathbf{i}}-\mathbf{r}_{\mathbf{i}}\right)=0.04$, which demonstrates that C53 affects the other three criteria C51, C52 and C54. That is, MNC should first improve C53 (Economies of scale), then the other three criteria: C51 (Industry cluster), C52 (Agglomeration economy) and C54 (Industrial Competitiveness) will be improved.

\section{CONCLUSION}

MNCs have developed their world expansion programs with the growth of globalization. The decision making of location selection becomes an important issue when MNCs expand overseas sites vigorously to develop the world market successfully. MNCs have to use appropriate research methods to evaluate various factors of location selection in determining the optimal sites for overseas investment. In this research, the evaluation indicators of location selection are selected by applying the Fuzzy Delphi method, which provides the evaluations of weights to choose total 25 vitalcriteria of location selection. The important indicators of location selection are determined by applying the Decision Making Trial and Evaluation Laboratory (DEMATEL) approach, which is an analytical method to clarify the essential of the decision making.Based on the measurement of DEMATEL method, D1 (Production Cost) has the highest degree of prominence $\left(\mathbf{d}_{\mathbf{i}}+\mathbf{r}_{\mathbf{i}}\right)$. Also, D5 (Industry Characteristics) has the highest degree of effect $\left(\mathbf{d}_{\mathbf{i}}-\mathbf{r}_{\mathbf{i}}\right)$. Within dimension of Production Cost (D1), C14 (Land costs) has the highest value of effect. Within dimension of Infrastructure (D2), C23 (Political and Economic conditions) has the highest value of effect. Within dimension of Investment Environment (D3), C31 (Social systems) has the highest value of effect. Within dimension of Government Policy (D4), C42 (Administrative efficiency) has the highest value of effect. Finally, within dimension of Industry Characteristics (D5), C53 (Economies of scale) has the highest value of effect. Those important dimensions and criteria are applied to evaluate the optimal location of overseas investment.

\section{REFERENCES}

[1] Z. Xu, "A deviation-based approach to intuitionistic fuzzy multiple attribute group decision making," Group Decision and Negotiation, vol. 19, no. 1, pp. 57-76, 2010.

[2] C. Wu and W. Fang, "Combining the fuzzy analytic hierarchy process and the fuzzy delphi method for developing critical competences of electronic commerce professional managers," Quality and Quantity, vol. 45 , no. 4 , pp. $751-768,2011$.

[3] G. H. Tzeng et al., "Evaluating intertwined effects in elearningprograms: A novel hybrid MCDM model based on factor analysis and DEMATEL," Expert Systems with Applications, vol. 32, no. 4, pp. 1028-1044, 2007.

[4] E. Frazelle, Supply Chain Strategy: The Logistics of Supply Chain Management, New York: McGraw-Hill, 2002.

[5] J. Brimberg and R. F. Love, "Global convergence of a generalized iterative procedure for the minisum location problem with $-p$ distances," Operations Research, vol. 41, pp. 1153-1163, 1993.

[6] J. Raymond and J. Mataloni, "The structure of location choice for new U.S. manufacturing investments in Asia-Pacific," Journal of World Business, vol. 46, no. 2, pp. 154-165, 2004.

[7] W. J. Stevenson, Production/operations management, 4th ed, Richard D. Irwin Inc., Homewood, 1993.

[8] Y. Kang and F. Jiang, "FDI location choice of Chinese multinationals in East and Southeast Asia: Traditional economic factors and institutional perspective," Journal of World Business, vol. 47, no. 1, pp. 45-53, 2012.

[9] H. S. Lei and Y. S. Chen, "The right tree for the right bird: Location choice decision of Taiwanese firms' FDI in China and Vietnam," International Business Review, vol. 20, pp. 338-352, 2011.

[10] B. G. Ohlin, P. O. Hesselborn, and P. M. Wijkman, "The international allocation of economic activity," presented at a Nobel symposium held at Stockholm, New York: Holmes \& Meier Publishers, 1976.

[11] B. Esiyok and M. Ugur, Foreign direct investment in provinces: A spatial regression approach to FDI in Vietnam, MPRA Paper, 36145, University Library of Munich, Germany, 05 Jan. 2012.

[12] J. H. Dunning, "Commentary: How Should National Governments Respond to Globalization?" The International Executive, vol. 35, no. 3 , pp. 187-198, 1993.

[13] J. H. Dunning, "Reappraising the eclectic paradigm in an age of alliance capitalism," Journal of InternationalBusiness Studies, vol. 26, no. 3, pp. 461-491, 1995.

[14] H. J. Stüting, W. Dorow, S. Blazejewski, and F. Claassen,"Change Management in Transition Economies: Integrating Corporate Strategy," Structure and Culture, Basingstoke, United Kindom: Palgrave Macmillan Publisher, 2003.

[15] A. Weber, Theory of the Location of Industries, Chicago: The University of Chicago Press, 1929.

[16] Tradingeconomics. (September 2013). Vietnam GDP Annual Growth Rate. [Online]. Available: http://www.tradingeconomics.com/vietnam/gdp-growth-annual

[17] B. L. Shieh and T. C. Wu, "Equity-based entry modes of the Greater Chinese Economic Area's foreign direct investments in Vietnam," International Business Review, vol. 21, no. 3, pp. 508-517, 2012.

[18] The Vietnam News Agency (2012). Nation records 5.03\% GDP growth. Single Digit CPI. [Online]. Available: http://en.vietnamplus.vn/Home/Nation-records-503-GDP-growth-sing le-digit-CPI/201212/30795.vnplus

[19] General Statistics Office of Vietnam. (2014). Statistical data, export and import of goods. [Online]. Available: http://www.gso.gov.vn/default_en.aspx?tabid=472\&idmid=3\&ItemID $=14616$

[20] Indexmundi. (2013). Vietnam Economy Profile 2013. [Online]. Available: http://www.indexmundi.com/vietnam/economy_profile.html

[21] A. L. Delbecq et al., Group techniques for program planning, Glenview, IL: Scott, Foresman, and Co., 1975

[22] J. Osborne, S. Collins, M. Ratcliffe, R. Millar, and R. Duschl, "What 'ideasabout-science' should be taught in school science?" A Delphi Study of the Expertcommunity. Journal of Research in Science Teaching, vol. 40, no. 7, pp. 692-720, 2003.

[23] N. P. Uhl, "Using the Delphi technique in institutional planning," New Directions for Institutional Research, vol. 37, no. 10, pp. 81-94, 1983.

[24] C. H. Wu, "Combing the fuzzy analytic hierarchy process and the fuzzy delphi method for developing critical competences of electronic commerce professional managers," Qual Quant, vol. 45, pp. 751-768, 2011.

[25] A. Ishikawa et al., "The Max-Min Delphi method and fuzzy Delphi method via fuzzy integration," Fuzzy Sets System, vol. 55, no. 3, pp. 241-253, 1993. 
[26] T. L. Saaty, Decision Making for Leaders: The Analytic Hierarchy Process for Decisions in a Complex World, New Edition 2001, $3^{\text {rd }}$ ed., RWS Publications: Pittsburgh, 1999.

[27] E. S. Lee and R. L. Li, "Comparison of fuzzy numbers based on the probability measure of fuzzy events," Computers and Mathematics with Applications, vol. 15, pp. 887-896, 1988.

[28] F.Wu, Y. Lee, and M. Lin, "Using the fuzzy analytic hierarchy process onoptimum spatial allocation," International Journal of Industrial Ergonomics, vol. 33, pp. 553-569, 2004.

[29] W. W. Wu and Y. T. Lee, "Developing global managers' competencies using the fuzzy DEMATEL method," Expert Systems with Applications, vol. 32, no. 2, pp. 499-507, 2007.

[30] C. L. Lin and G. H. Tzeng, "A value-created system of science (technology) parkby using DEMATEL," Expert Systems with Applications, vol. 36, no. 6, pp. 9683-9697, 2009.

[31] Y. C. Chen, H. P. Lien, and G. H. Tzeng, "Measures and evaluation for environment watershed plans using a novel hybrid MCDM model," Expert Systems with Applications, vol. 37, no. 2, pp. 926-938, 2010.

[32] M. Tamura, H. Nagata, and K. Akazawa, Extraction and systems analysis of factors that prevent safety and security by structural models presented at 41st SICE annual conference, Osaka, Japan, 2002.
[33] G. H. Tzeng, C. H. Chiang, and C. W. Li, "Evaluating Intertwined effects in e-learning programs: A novel hybrid mcdm model based on factor analysis and DEMATEL," Expert Systems with Applications, vol. 32, no. 4, pp. 1028-1044, 2007.

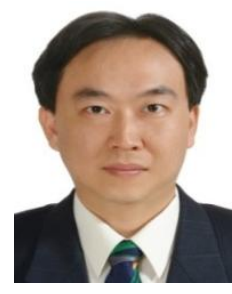

Weng-Kun Liu is an assistant professor at Feng Chia University in Taiwan. He majors in management administration and concentrates in the arena of international business management. He dedicates his interest in the researches of international business management, leadership behavior, fuzzy theory, and decision making. He also devotes the researches of industry-academy cooperation to enhance the practical production output. He is a senior member of the International Economics Development and Research Center (IEDRC) and served as a session chair of 2012 International Conference on Government, Law and Culture (ICGLC) on 2012, January $7^{\text {th }}$, Hong Kong. $\mathrm{He}$ also served as a referee of The International Journal of Human Resource Management (IJHRM) (SSCI) in 2013 and Journal of Organizational Change Management (JOCM) (SSCI) in 2014. 